\title{
Shelly fossils from the lower Cambrian White Point Conglomerate, Kangaroo Island, South Australia
}

Marissa J. Betts, Thomas M. Claybourn, Glenn A. Brock, James B. Jago, Christian B. Skovsted, and John R. Paterson

Acta Palaeontologica Polonica 64 (3), 2019: 489-522 doi:https://doi.org/10.4202/app.00586.2018

The lower Cambrian (Series 2) White Point Conglomerate (WPC) on Kangaroo Island, South Australia contains exotic clasts representing a diverse array of lithologies, including metamorphics, chert, sandstone, and abundant carbonates, notably archaeocyath-rich bioclastic limestone. Acetic acid digestion of the WPC bioclastic limestone clasts reveals a diverse shelly fauna. This assemblage includes abundant organophosphatic brachiopods such as Cordatia erinae Brock and Claybourn gen. et sp. nov., Curdus pararaensis, Eodicellomus elkaniformiis, Eohadrotreta sp. cf. E. zhenbaensis, Eoobolus sp., Kyrshabaktella davidii, and Schizopholis yorkensis.

Additional shelly taxa include the solenopleurid trilobite Trachoparia? sp., the tommotiids Dailyatia odyssei, Dailyatia decobruta Betts sp. nov., Kelanella sp., and Lapworthella fasciculata, spines of the bradoriid arthropod Mongolitubulus squamifer, and several problematica, such as Stoibostrombus crenulatus and a variety of tubular forms. The upper age limit for the WPC is constrained by biostratigraphic data from the overlying Marsden Sandstone and Emu Bay Shale, which are no younger than the Pararaia janeae Trilobite Zone (Cambrian Series 2, Stage 4). The shelly fossil assemblage from the WPC limestone clasts indicates an upper Dailyatia odyssei Zone (= Pararaia tatei to lower P. janeae trilobite zones), equivalent to the Atdabanian-early Botoman of the Siberian scheme. This contrasts with the previously suggested late Botoman age for the limestone clasts, based on the diverse archaeocyath assemblage. The minor age difference between the WPC and its fossiliferous limestone clasts suggests relatively rapid reworking of biohermal buildups during tectonically-active phases of deposition in the Stansbury Basin.

Key words: Brachiopoda, Trilobita, Tommotiida, chronostratigraphy, early Cambrian, Australia.

Marissa J. Betts [marissa.betts@une.edu.au], Palaeoscience Research

Centre, School of Environmental and Rural Science, University of

New England, Armidale, NSW, Australia, 2351; Early Life Institute

and Department of Geology, State Key Laboratory for Continental

Dynamics, Northwest University, Xi'an 710069, China. Thomas M.

Claybourn [thomas.claybourn@hdr.mq.edu.au], Department of Biological

Sciences, Macquarie University, North Ryde, Sydney, NSW, Australia, 2109; 
Department of Earth Sciences, Palaeobiology, Uppsala University, Villav. 16,

SE-75236, Uppsala, Sweden. Glenn A. Brock [glenn.brock@mq.edu.au],

Department of Biological Sciences, Macquarie University, North Ryde, Sydney,

NSW, Australia, 2109. James B. Jago [jim.jago@unisa.edu.au], School of

Natural and Built Environments, University of South Australia, Mawson

Lakes, Adelaide, SA, Australia, 5005. Christian B. Skovsted [christian.skovsted@nrm.se

], Department of Palaeobiology, Swedish Museum of Natural History, Box 50007,

SE 10405 Stockholm, Sweden. John R. Paterson [jpater20@une.edu.au], Palaeoscience Research Centre,

School of Environmental and Rural Science, University of New England, Armidale, NSW, Australia, 2351.

This is an open-access article distributed under the terms of the Creative Commons

Attribution License (for details please see creativecommons.org), which permits unrestricted use,

distribution, and reproduction in any medium, provided the original author and source are credited.

FoF Full text $(3,204.4 \mathrm{kB})$ 